\title{
Growth and development of calves depending on the method of feeding with cereal and milk
}

\author{
Anna Sergeevna Karamaeva ${ }^{1}$, Sergey Vladimirovich Karamaev ${ }^{1, *}$, Khaidar Zufarovich Valitov ${ }^{1}$, Larisa Nikolaevna Bakae- \\ $\mathrm{va}^{2}$, and Natalya $V$. Soboleva ${ }^{2}$
}

${ }^{1}$ Samara State Agrarian University, 446442 Kinel, Samara Region, Russia

${ }^{2}$ Orenburg State Agrarian University, 460795 Orenburg, Russia

\begin{abstract}
The article studies the influence of the milk feeding method on the growth and development of calves. The object of research is newborn Samara black-motley calves. It was established that after drinking the first portion of colostrum, immunoglobulin appears in the blood of calves in 2 hours. Immunoglobulin enters the bloodstream in the first 12 hours of life. The highest content of immunoglobulin $(23.40 \mathrm{mg} / \mathrm{ml})$ was observed after 48 hours in case of free suckling. It exceeded that in peers fed manually by $6.7-8.9 \%$. Depending on the feeding scheme and method, the heifers consumed 497.0-509.4 kg of milk for three months in case of manual feeding, $589.5 \mathrm{~kg}$ for two months in case of free suckling, and $540.3 \mathrm{~kg}$ in case of regulated suckling. The technology of milk feeding, the time spent with a mother, the amount of milk consumed had a significant impact on the health of calves. The degree of calf morbidity had a significant impact on the growth and development of young animals. As a result of a greater consumption of milk and large volumes of feed, heifers under regulated suckling had a larger live weight than their peers aged 18 months by $11.1 \%$ ( $\mathrm{P}<0.001$ ) (in comparison with the peers from group I), by $16.0 \%$ ( $\mathrm{P}<0.001$ ) (in comparison with the peers from group II), by $17.5 \%$ ( $\mathrm{P}<0.001)$ (in comparison with the peers from group III), by $4.7 \%$ ( $\mathrm{P}<0.05$ ) (in comparison with the peers from group IV).
\end{abstract}

\section{Introduction}

Modern milk production technologies involve very harsh modes of use of animals. Therefore, when introducing intensive technologies into production, it is necessary to take into account biological and physiological properties of living organisms [1-6].

The intensive milk technology is based on the maximum use of genetically determined abilities of the animal organism. High physiological loads on the body which require the full use of internal reserves of nutrients and energy for their implementation, decrease immunity, natural resistance, resulting in premature departure of animals from the herd [7-11].

The issue of breeding calves and ensuring the herd reproduction is very acute. In modern dairy cattle breeding, the overall mortality rate for newborn calves ranges from 17 to $21 \%$; $55 \%$ of cases occur in the first week of life. More than $80 \%$ of dead calves do not have anatomical abnormalities [12, 13].

In order to unify and maximize mechanization of the method of feeding with colostrum and milk, newborn calves are immediately taken from their mothers. As a result of drinking colostrum and milk from nipple drinkers, the mortality of calves increases significantly, especially in the first months of their life [14-17].
The purpose of research is to study the effect of the method of drinking colostrum and milk on the health, growth and development of calves.

\section{Methods and materials}

The studies were conducted in the farm named after Kuibyshev, Samara Region, where the "manual" method is used to feed calves with colostrum and milk, and in the Yuzhny collective farm, Orenburg Region, where the suckling method is used. The research material was black-motley heifers with a Holstein blood share of $62.5 \%$, belonging to the lines of V. B. Aydial and R. Sowering with a milk yield (2-3 lactation) of 6836-7459 $\mathrm{kg}$.

In accordance with the research scheme, five groups were formed (50 animals in each group): control group I - the calves were left with their mothers for 3 days, experimental group II - the calves were left with their mothers for one day; experimental group III - the calves were immediately taken from their mothers, placed in individual houses and fed "manually" from nipple drinkers, experimental group IV - the suckling calves were kept in special sections with nursing cows for two months, experimental group V - the calves' cells were located near nursing cows, the calves were released three times a day for 10-15 min for regulated suckling. There were five cows in the section. Each cow fed two calves.

* Corresponding author: KaramaevSV@mail.ru 
At the exit, electronic scales that recorded the dynamics of a live weight before and after milk consumption were installed.

To study the dynamics of immunoglobulin, blood of 10 animals of each group was taken from the jugular vein during the first five days of their lives after taking the first portion of colostrum. The content of immunoglobulin was determined using an FEK-456M device. During the first three months, all signs of health disorders were recorded in calves, determining the incidence rate.

\section{Results}

Calves losing contact with their mothers are unprotected from negative effects of environmental factors and various microorganisms that begin to populate their body. In this regard, it is very important to feed calves with colostrum no later than 60 minutes after their birth. Due to it, immunoglobulin appears in blood as soon as possible and protects their immune system. It was established that intensity of the dynamics of immunoglobulin content depends on the colostrum drinking method (Table 1).

After drinking the first portion of colostrum, immunoglobulin appears in the bloodstream. According to Georgiev [11], immunoglobulins performs a protective function at a concentration of at least $10 \mathrm{mg} / \mathrm{ml}$. This concentration is achieved 6 hours after drinking the first portion of colostrum. Immoglobulin enters the blood most intensively in the first 12 hours of life. At the same time, in the blood of calves under regulated suckling, the content of immunoglobulin was higher by $1.85 \mathrm{mg} / \mathrm{ml}$
$(14.2 \%)$ in comparison with group III which was under "manual" feeding, and by $0.16-0.03 \mathrm{mg} / \mathrm{ml}(1.1-0.2 \%)$ in comparison with the group which was under free suckling. The content of immunoglobulin increases within 48 hours after drinking the first portion of colostrum. The highest content $(23.40 \mathrm{mg} / \mathrm{ml})$ was observed in the blood of calves under free suckling; it exceeded the content in their peers under "manual" feeding by 1.46-1.91 $\mathrm{mg} / \mathrm{ml}(6.7-8.9 \%)$. The difference is statistically not significant, since the groups have a very high coefficient of variability for this indicator (19.4-21.6\%).

The studies have shown that the method of drinking colostrum had a certain effect on the intensity of assimilation of immunoglobulin in the body of heifers (Table 2 ). Sox hours after the first portion of colostrum was drunk, the share of calves with immunoglobulin content of more than $10 \mathrm{mg} / \mathrm{ml}$ was the same (58-64\%) in groups I, II, IV and V; in group III which was under "manual" feeding, it was $32 \%$ (by $26-32 \%$ less).

A. Fox [14] notes that when immunoglobulin content is less than $6 \mathrm{mg} / \mathrm{ml}$, colostral immunity does not work. Such calves are susceptible to various diseases, especially those of the gastrointestinal tract. The share of calves poorly absorbing immunoglobulin from colostrum was $2-8 \%$ in groups under free suckling, and $28 \%$ in groups under manual feeding.

During the "manual" feeding, the calves received whole milk for three months, their peers were kept under nursing cows for two months. The feeding schedule suggested that calves consumed $500 \mathrm{~kg}$ of milk during the dairy period (Table 3 ).

Table 1. Dynamics of immunoglobulin in the blood of newborn calves after drinking the first portion of colostrum, $\mathrm{mg} / \mathrm{ml}$

\begin{tabular}{|c|c|c|c|c|c|}
\hline \multirow{2}{*}{$\begin{array}{l}\text { Time after drinking } \\
\text { colostrum, } \mathrm{h}\end{array}$} & \multicolumn{5}{|c|}{ Group } \\
\hline & $\mathrm{I}$ & II & III & IV & $\mathrm{V}$ \\
\hline $\begin{array}{l}\text { Before taking } \\
\text { colostrum }\end{array}$ & $0.17 \pm 0.01$ & $0.18 \pm 0.01$ & $0.20 \pm 0.01$ & $0.19 \pm 0.01$ & $0.18 \pm 0.01$ \\
\hline 1 & $0.32 \pm 0.13$ & $0.29 \pm 0.18$ & $0.24 \pm 0.14$ & $0.28 \pm 0.21$ & $0.30 \pm 0.16$ \\
\hline 2 & $2.50 \pm 0.30$ & $2.52 \pm 0.34$ & $2.39 \pm 0.26$ & $2.96 \pm 0.39$ & $2.84 \pm 0.23$ \\
\hline 4 & $6.57 \pm 0.54$ & $6.48 \pm 0.67$ & $5.96 \pm 0.49$ & $6.78 \pm 0.852$ & $6.43 \pm 0.47$ \\
\hline 6 & $10.81 \pm 0.88$ & $10.75 \pm 0.93$ & $9.48 \pm 0.66$ & $10.94 \pm 0.74$ & $10.87 \pm 0.65$ \\
\hline 12 & $14.79 \pm 1.21$ & $14.76 \pm 1.24$ & $13.07 \pm 0.87$ & $14.89 \pm 0.95$ & $14.92 \pm 0.86$ \\
\hline 24 & $22.86 \pm 0.93$ & $22.78 \pm 0.96$ & $20.79 \pm 0.99$ & $22.83 \pm 1.04$ & $22.89 \pm 0.94$ \\
\hline 36 & $22.98 \pm 1.36$ & $21.83 \pm 0.84$ & $21.34 \pm 1.12$ & $22.90 \pm 0.93$ & $22.96 \pm 0.88$ \\
\hline 48 & $23.37 \pm 1.12$ & $21.94 \pm 0.79$ & $21.49 \pm 0.86$ & $23.40 \pm 0.96$ & $23.34 \pm 0.85$ \\
\hline 72 & $22.88 \pm 0.97$ & $21.69 \pm 0.81$ & $21.38 \pm 0.79$ & $22.97 \pm 0.82$ & $22.84 \pm 0.91$ \\
\hline 120 & $21.83 \pm 0.86$ & $21.46 \pm 0.76$ & $21.25 \pm 0.82$ & $22.76 \pm 0.87$ & $22.69 \pm 0.79$ \\
\hline
\end{tabular}

Table 2. Intensity of the transition of immunoglobulin from colostrum to blood of calves during the first 6 hours after feeding

\begin{tabular}{|c|c|c|c|c|c|c|c|c|c|c|}
\hline \multirow{3}{*}{$\begin{array}{l}\text { The content of immuno- } \\
\text { globulin in blood, } \mathrm{mg} / \mathrm{ml}\end{array}$} & \multicolumn{10}{|c|}{ Group } \\
\hline & \multicolumn{2}{|c|}{ I } & \multicolumn{2}{|c|}{ II } & \multicolumn{2}{|c|}{ III } & \multicolumn{2}{|c|}{ IV } & \multicolumn{2}{|c|}{$\mathrm{V}$} \\
\hline & heads & $\%$ & heads & $\%$ & heads & $\%$ & heads & $\%$ & heads & $\%$ \\
\hline less than 4.0 & - & - & 1 & 2.0 & 6 & 12.0 & - & - & - & - \\
\hline $4.1-6.0$ & 2 & 4.0 & 3 & 6.0 & 8 & 16.0 & 1 & 2.0 & 2 & 4.0 \\
\hline $6.1-8.0$ & 8 & 16.0 & 7 & 14.0 & 10 & 20.0 & 7 & 14.0 & 6 & 12.0 \\
\hline $8.1-10.0$ & 11 & 22.0 & 9 & 18.0 & 10 & 20.0 & 10 & 20.0 & 12 & 24.0 \\
\hline $10.1-12.0$ & 17 & 34.0 & 15 & 30.0 & 14 & 28.0 & 19 & 38.0 & 16 & 32.0 \\
\hline more than 12.0 & 12 & 24.0 & 15 & 30.0 & 2 & 430 & 13 & 26.0 & 14 & 28.0 \\
\hline
\end{tabular}


Table 3. The number of feedings and the amount of consumed milk during different age periods

\begin{tabular}{|c|c|c|c|c|c|}
\hline \multirow{2}{*}{ Indicator } & \multicolumn{5}{|c|}{ Group } \\
\hline & I & II & III & IV & $\mathrm{V}$ \\
\hline \multicolumn{6}{|c|}{ Colostrum ( $1^{\text {st }}$ day after birth $)$} \\
\hline Number of feedings & 6 & 5 & 4 & 6 & 5 \\
\hline Colostrum consumption, $\mathrm{kg}$ & 8.4 & 8.0 & 8.0 & 8.4 & 9.0 \\
\hline including per one feeding, $\mathrm{kg}$ & 1.4 & 1.6 & 2.0 & 1.4 & 1.8 \\
\hline \multicolumn{6}{|c|}{ Milk (30th day after birth) } \\
\hline Number of feedings & 3 & 3 & 3 & 9 & 3 \\
\hline Colostrum consumption, $\mathrm{kg}$ & 6.0 & 6.0 & 6.0 & 9.9 & 8.7 \\
\hline including per one feeding, $\mathrm{kg}$ & 2.0 & 2.0 & 2.0 & 1.1 & 2.9 \\
\hline \multicolumn{6}{|c|}{ Milk (60th day after birth) } \\
\hline Number of feedings & 3 & 3 & 3 & 7 & 3 \\
\hline Colostrum consumption, $\mathrm{kg}$ & 6.0 & 6.0 & 6.0 & 9.8 & 9.3 \\
\hline including per one feeding, $\mathrm{kg}$ & 2.0 & 2.0 & 2.0 & 1.4 & 3.1 \\
\hline \multicolumn{6}{|c|}{ Milk (90th day after birth) } \\
\hline Number of feedings & 3 & 3 & 3 & - & - \\
\hline Colostrum consumption, $\mathrm{kg}$ & 4.5 & 4.5 & 4.5 & - & - \\
\hline including per one feeding, $\mathrm{kg}$ & 1.5 & 1.5 & 1.5 & - & - \\
\hline TOTAL & 509.4 & 500.9 & 497.0 & 589.5 & 540.3 \\
\hline
\end{tabular}

Table 4. The incidence of calves for three months of the dairy period

\begin{tabular}{|c|c|c|c|c|c|c|c|c|c|c|}
\hline \multirow{3}{*}{$\begin{array}{c}\text { The age of calves, } \\
\text { days }\end{array}$} & \multicolumn{10}{|c|}{ Group } \\
\hline & \multicolumn{2}{|c|}{ I } & \multicolumn{2}{|c|}{ II } & \multicolumn{2}{|c|}{ III } & \multicolumn{2}{|c|}{ IV } & \multicolumn{2}{|c|}{$\mathrm{V}$} \\
\hline & heads & $\%$ & heads & $\%$ & heads & $\%$ & heads & $\%$ & heads & $\%$ \\
\hline $1-10$ & 1 & 2.0 & 3 & 6.0 & 8 & 16.0 & - & - & - & - \\
\hline $11-20$ & 2 & 4.0 & 5 & 10.0 & 6 & 12.0 & 1 & 2.0 & 1 & 2.0 \\
\hline $21-30$ & 4 & 8.0 & 6 & 12.0 & 3 & 6.0 & 2 & 4.0 & 1 & 2.0 \\
\hline $31-60$ & 3 & 6.0 & 1 & 2.0 & 3 & 6.0 & 1 & 2.0 & 1 & 2.0 \\
\hline $61-90$ & 2 & 4.0 & 2 & 4.0 & 1 & 2.0 & 4 & 8.0 & 4 & 8.0 \\
\hline Total & 12 & 24.0 & 17 & 34.0 & 21 & 42.0 & 8 & 16.0 & 9 & 14.0 \\
\hline
\end{tabular}

Table 5. Age dynamics of a live weight of heifers

\begin{tabular}{|c|c|c|c|c|c|}
\hline \multirow{2}{*}{ Indicator } & \multicolumn{5}{|c|}{ Group } \\
\cline { 2 - 6 } & I & II & III & IV & V \\
\hline $\begin{array}{c}\text { New-born } \\
\text { calves }\end{array}$ & $33.87 \pm 0.54$ & $34.03 \pm 0.46$ & $34.45 \pm 0.49$ & $34.68 \pm 0.47$ & $33.94 \pm 0.43$ \\
\hline 1 & $53.91 \pm 0.89 * *$ & $53.29 \pm 0.67 * * *$ & $52.87 \pm 0.93 * * *$ & $57.45 \pm 0.78$ & $56.02 \pm 0.81$ \\
\hline 2 & $76.11 \pm 1.46^{* *}$ & $74.68 \pm 1.35^{* * *}$ & $73.75 \pm 1.58^{* * *}$ & $82.47 \pm 1.29$ & $81.19 \pm 1.44$ \\
\hline 3 & $99.03 \pm 1.88^{* *}$ & $96.85 \pm 1.73 * * *$ & $95.59 \pm 1.64 * * *$ & $107.73 \pm 1.78$ & $106.87 \pm 1.86$ \\
\hline 6 & $163.92 \pm 2.56^{* * *}$ & $158.68 \pm 2.34 * * *$ & $156.25 \pm 2.18^{* * *}$ & $176.94 \pm 2.43^{* *}$ & $186.34 \pm 2.29$ \\
\hline 9 & $224.67 \pm 3.31 * * *$ & $215.74 \pm 3.52^{* * *}$ & $212.32 \pm 3.45^{* * *}$ & $242.19 \pm 3.64 *$ & $252.85 \pm 3.37$ \\
\hline 12 & $282.99 \pm 4.54 * * *$ & $270.91 \pm 4.68^{* * *}$ & $265.96 \pm 4.32^{* * *}$ & $303.75 \pm 4.27 *$ & $316.75 \pm 4.42$ \\
\hline 15 & $339.16 \pm 5.48^{* * *}$ & $323.65 \pm 5.26^{* * *}$ & $319.17 \pm 5.39^{* * *}$ & $361.08 \pm 5.43 *$ & $376.96 \pm 4.98$ \\
\hline 18 & $391 \pm 5.87 * * *$ & $374.86 \pm 6.43^{* * *}$ & $369.95 \pm 6.21 * * *$ & $415.17 \pm 5.79 *$ & $434.83 \pm 6.35$ \\
\hline
\end{tabular}

Note: $* \mathrm{P}<0.05 \% ; * * \mathrm{P}<0.01 \% ; * * * \mathrm{P}<0.001$

As a result of observations, it was found that calves under free suckling drank 6-7 times more milk. Under regulated suckling, calves were placed under the nursing cow 5 times; under "manual" feeding, they were fed 4 times a day. Thus, on the first day, they received 8.0-9.0 $\mathrm{kg}$ of colostrum, while under manual feeding $-8.0 \mathrm{~kg}$. This is higher than the technological norm which is $20 \%$ of the live weight $-6.8 \mathrm{~kg}$.

When using nipple drinkers, calves of the first three groups were fed three times a day; under regulated suckling (group V), they were placed under the nursing cows 3 times; under free suckling, the calves determined the mode of milk consumption. During the first 30 days, the average number of sucklings per day was 9, during the next 30 days, it was 7 times. During "manual" drinking, milk consumption was uniform. For one feeding, they consumed $2 \mathrm{~kg}$ of milk (6 kg per day). Suckling calves consumed $9.9 \mathrm{~kg}$ of milk per day; the single portion was $1.1 \mathrm{~kg}$. The regulated suckling did not limit the duration of a single sucking which ensured the consumption of 8.7 $\mathrm{kg}$ of milk per day.

Thus, under manual feeding, the calves consumed 497.0-509.4 kg of milk during three months; under free suckling - $589.5 \mathrm{~kg}$ during two months, and under regulated suckling $-540.3 \mathrm{~kg}$.

The milk drinking method, the time spent with mothers, the amount of milk consumed during the dairy period 
had a significant impact on the incidence of calves (Table 4).

Taking into account any signs of diseases showed that being with mothers and consuming milk by the suckling method had a positive effect on the health of heifers. As practice shows, the first 10 days are the most dangerous for the health of calves. During this period, the body lacks immunity, and properties of colostrum are the only protection against the influence of pathogenic microflora. In groups IV and V, there were no signs of diseases during the 10th days. Under manual feeding, when new-born calves were left with their mothers for three days, one calf $(2.0 \%)$ fell ill; in group II, where new-born calves were with their mothers during one day, three calves fell ill $(6,0 \%)$; in group III, where the newborns were immediately taken away from their mothers, 8 calves fell ill $(16.0 \%)$

The incidence of young animals increased after beginning of the manual feeding. Between 11 and 90 days of life, $22 \%$ of calves fell ill in group I, $28 \%$ in group II, and $26 \%$ in group III. The highest incidence was observed in group III, where the calves were immediately taken from the mothers. The study of the main sources of milk infection showed that $220-680 \mathrm{pcs} / \mathrm{ml}$ microorganisms are concentrated in the nipple canal of the udder, $8000-16500 \mathrm{pcs} / \mathrm{ml}$ - on the surface of the nipples, 1350 $\mathrm{pcs} / \mathrm{ml} \mathrm{-} \mathrm{on} \mathrm{the} \mathrm{surface} \mathrm{of} \mathrm{the} \mathrm{nipple} \mathrm{drinkers,} \mathrm{and} 2700$ $\mathrm{pcs} / \mathrm{ml}$ - on the internal side of the milk tank. Thus, a probability of transmission of pathogenic microflora to the calf is several times higher. For two months of the milk period, only $8 \%$ fell ill in group IV, and $6 \%$ - in group V. After weaning, $8 \%$ of calves in each group fell ill within a month due to the influence of stress.

Specific immunity determines health of calves (Table 5).

The heifers in all groups were bred using the same technology for young dairy breeds. The main objective was breeding young animals with a live weight of $390 \mathrm{~kg}$ at the age of 18 months. According to the results of the studies, the task was achieved only using the technology adopted in groups I, IV, and V. The heifers of group IV reached a minimum live weight at the age of 17 months, group $\mathrm{V}-$ at the age of 16 months, and group I - only at the age of 18 months.

It was established that the higher the incidence, the more the calves lagged behind their peers in growth and development. At the age of two months, when the calves were weaned, the maximum live weight $(82.47 \mathrm{~kg})$ was observed in suckling heifers. The weight exceeded that of their peers in group I by $6.36 \mathrm{~kg}(8.4 \%$; $\mathrm{P}<0.01)$, in group II - by $7.79 \mathrm{~kg}(10.4 \%$; $\mathrm{P}<0.001)$, in group III - by 8.72 $\mathrm{kg}(11.8 \%$; $\mathrm{P}<0.001)$, and in group $\mathrm{V}-$ by $1.28 \mathrm{~kg}$ $(1.6 \%)$. It should be noted that the regulated suckling (3 times a day) stimulated calves to consume more voluminous and concentrated feeds which positively affected the development of the gastrointestinal tract. As a result of greater consumption of voluminous feed, heifers of group $\mathrm{V}$ had a larger live weight than their their peers (by 22.42 $\mathrm{kg}(13.7 \% ; \mathrm{P}<0.001)$ in comparison with group I), by $27.66 \mathrm{~kg}(17.4 \% ; \mathrm{P}<0.001)$ in comparison with group II, by $30,09 \mathrm{~kg}(19.3 \% ; \mathrm{P}<0.001)$ in comparison with group III, by $9.4 \mathrm{~kg}(5.3 \%$; $\mathrm{P}<0.01)$ in comparison with group
IV. At the age of 12 months, the difference was $33.76 \mathrm{~kg}$, (11.9\%; $\mathrm{P}<0.001) ; 45.84 \mathrm{~kg}(16.9 \% ; \mathrm{P}<0.001) ; 50.79 \mathrm{~kg}$ $(19.1 \% ; \mathrm{P}<0.001) ; 13.0 \mathrm{~kg}(4.3 \% ; \mathrm{P}<0.05)$, respectively. At the age of 18 months, the difference was $43.47 \mathrm{~kg}$ $(11.1 \% ; \mathrm{P}<0.001) ; 59.97 \mathrm{~kg}(16.0 \% ; \mathrm{P}<0.001) ; 64.88 \mathrm{~kg}$ (17.5\%; $\mathrm{P}<0.001) ; 19.66 \mathrm{~kg}(4.7 \% ; \mathrm{P}<0.05)$, respectively.

\section{Conclusion}

Thus, the method of feeding with colostrum and milk, the duration of being with mothers after birth, the amount of milk consumed have a significant impact on the immune system and determine the resistance to diseases, affect the growth rate and the development of young animals. In accordance with the plan for breeding dairy cows with different levels of milk productivity, the feeding options make it possible to breed heifers with a live weight characteristic of future cows with a milk yield of 6-6.5 thousand $\mathrm{kg}$ by the 18 month-age; the use of the suckling method makes it possible to breed cows with a milk yield of 7-8 thousand $\mathrm{kg}$. Regulated suckling reduces the cost of milk per head per $49 \mathrm{~kg}$, stimulates the consumption of bulky feed, which increases the growth rate and the live weight of adult animals.

\section{References}

1. A.I. Afanasyeva, V.G. Oguy, N.V. Myakushko, Technological tools of adaptive methods for breeding calves 32-69 (Altai State Agrarian university, Barnaul, 2006)

2. D.I. Fayzrakhmanov, M.G. Nurtdinov, A.N. Khayrullin, et al., The organization of dairy cattle breeding based on technological innovation 90-126 (Kazan State University, Kazan, 2007)

3. S.V. Karamaev, L.N. Bakaeva, A.S. Karamaeva, et al., Breeding of Holstein cattle in the Middle Volga region 118-174 (RIO of Samara State Agricultural Academy, Kinel, 2018)

4. L.P. Zaripova, F.S. Gibadullina, Sh.K. Shakirov, et al., Feed of the Republic of Tatarstan: Composition, $\mathrm{Nu}$ trition and Use 81-122 (Foliant, Kazan, 2010)

5. R.M. Akers, Lactation and the mammary gland 89-124 (Iowa State Press, Blackwell Publishing Company, 2002)

6. R.M. Akers, Major advances associated with hormone and growth factor regulation of mammary growth and lactation in dairy cows J. Dairy Sci., 89(4), 1222-1234 (2006)

7. J.D. Quigley, Passive immunity in newborn calves 2010 Retrieved from: http://www.weds.ca

8. D. Hesecke, Matabolische Litungagrenzen bei kuhen 531-535 (Medizin, Berlin, 1991)

9. L.C. Pritchett, C.C. Gay, T.E. Besser, D.D. Hancock, Management and production factors influencing immunoglobulin Giconcentration in colostrums from Holstein cows J. Dairy Sci., 74, 2336 (1991) 
10. Zoge Alois, Uber die Beeinflussung der individuellen Disposition zu Infektionskrankheiten durch Warmentzungang. I. Ab-handlung, Archiv f. Hygiene, Bd. 28, 344-396 (1997)

11. I.P. Georgiev, Differences in chemical composition between cow colostrums and milk Bulg. J. Veter. Med. 11(1), 3-12 (2008)

12. L.N. Bakaeva, A.S. Karamaev, S.V. Karamaev, The formation of immune status in newborn dairy and combined calves Dairy and beef cattle breeding $\mathbf{1}$, 32-37 (2019)

13. E.N. Motova, Evaluation of the biochemical and immune status of calves in the early postnatal period when evaporating frozen colostrum with a high content of immunoglobulins Agricultural Biology 2, 8487 (2008)
14. A. Fox, A. Kleinsmith, Scientific and medical research related to bovine colostrums. Its relationship and use in the treatment of disease in humans Selected publishers abstracts (2010) Retrieved from: http://www.immunetree.com

15. D.E. Morin, G.C. McCoy, W.L. Hurley, Effects of quality, quantity, and timing of colostrums feeding and addition of a dried colostrums supplement on immunoglobulin Gi absorption in Holstein bull calves J. Dairy Sci. 80(4), 747-753 (1997)

16. A.W. Scammell, Production and uses of colostrum Austr. J. Dairy Techn. 56(2), 74-82 (2001)

17. S. Zarcula, H. Cemescu, C. Mircu, C. Tulcan, A. Morvay, S. Baul, D. Popovici, Influence of breed, parity and food intake on chemical composition of first colostrum in cow Anim. Sci. Biotechn. 43(1), 154-157 (2010) 